\title{
Waterfront Land Use Change and Marine Resource Conditions: The Case of New Bedford and Fairhaven, Massachusetts
}

\author{
Michelle E. Portman, ${ }^{a^{*}}$ Di Jin, ${ }^{a}$ and Eric Thunberg ${ }^{\mathrm{b}}$ \\ ${ }^{\mathrm{a}}$ Marine Policy Center \\ Woods Hole Oceanographic Institution \\ Woods Hole, MA 02543, USA \\ ${ }^{\mathrm{b}}$ Social Sciences Branch \\ Northeast Fisheries Science Center \\ National Marine Fisheries Service \\ Woods Hole, MA 02543, USA
}

\begin{abstract}
A major challenge in gauging long-term and cumulative impacts of fisheries management on coastal fishing communities is the lack of understanding of the interactions between changes in fish stocks and waterfront land uses. This study examines these interactions in the New Bedford/Fairhaven area using parcel level data and geographic information system (GIS) tools. Logistic regression models were used to assess the impact of changes in marine resource abundance on waterfront land uses. Although land-use decisions are influenced by many complex market and regulatory factors, our study detected a significant relationship between fish stock conditions and coastal land uses.
\end{abstract}

Keywords: Atlantic sea scallop, coastal land use, fisheries management, fish biomass, waterfronts, spatial analysis

*Corresponding author. Tel.:+1-508-289-2773; fax: +1-508-457-2184.

E-mail address: mportman@whoi.edu (M. E. Portman).

Acknowledgements: This research was supported by the National Atmospheric and Oceanic Administration (NOAA) through the WHOI/NOAA Cooperative Institute on Climate and Ocean Research (CICOR) under award number NA17RJ1223 and by the Marine Policy Center of the Woods Hole Oceanographic Institution. The authors are also grateful for the comments of Fred Serchuk of NOAA's National Marine Fisheries Service and two anonymous reviewers. 


\section{Introduction}

Many New England fish stocks have been categorized as "overfished”" in recent decades (Hennessey and Healey, 2000; Sutinen and Upton, 2000; NOAA National Marine Fisheries Service, 2008a). This situation reflects trends in fisheries worldwide (Food and Agriculture Organization, 2006). Declining stocks and subsequent management measures aimed at allowing exploited stocks to recover and rebuild bring about much political controversy, highlighting the link between communities of fish and humans.

The idea that interactions between fishery resources and people are important is not new. However it is also true that while the population dynamics of fish stocks have received considerable attention in academic literature, the dynamics of various aspects of human communities dependent on fisheries have received considerably less. Among the aspects of fishing communities neglected in relation to fish stocks are coastal land uses. How waterfronts are used tells us a lot about how commercial fisheries and communities are connected (Hershman, 1988).

While there is a body of literature on the impacts of land uses on the marine environment (e.g., how land-based pollution reaches and affects marine resources), little attention has been paid to landward affects of what goes on in the sea, especially from a spatial perspective. Studies of land side change resulting from fisheries change and from overfishing commonly address community economic and social organization or focus on

\footnotetext{
${ }^{1}$ Using the categorization scheme accepted by the New England and Mid-Atlantic Fishery Management Councils, of the 62 finfish and invertebrate stocks reviewed, 19 are considered to be overfished and 10 are currently experiencing overfishing. For 14 stocks, their status with respect to overfished cannot presently be determined and hence these stocks are classified as 'Status Unknown' (NOAA National Marine Fisheries Service, 2008a).
} 
lost employment or revenues. Studies analyzing quantitative spatial variations, such as shifts in land use over time, are lacking.

In this study, an approach is presented that relates spatial data - land use changes in localized waterfront properties - to marine resource conditions. The focal question is: do observed land use changes reflect changes in the fisheries industry? This study uses GIS to aid in quantifying land uses changes in the study area over the past 20 years and then relates these changes to secondary statistical data available on the fisheries for this period. The New Bedford/Fairhaven Harbor serves as a case study. The analytical framework of this study can be expanded to other commercial fishing ports for a more comprehensive state or regional picture. Such empirical analysis will aid in identifying spatial changes along waterfront communities in New England at a local level, an important step in predicting consequences of further changes in resource conditions and policy.

This paper begins with a brief summary of literature that deals with the connection between coastal land use and marine resource conditions and the importance of understanding these relationships. Section 3 describes the case study area. Section 4 presents the methods used. Data for the analyses and regression results are discussed in Sections 5 and 6 respectively. The penultimate section of the paper points out some limitations of the method. The final section draws conclusions and makes some recommendations for future research.

\section{Fisheries and Communities}

Studies relating fisheries management to human communities usually focus on three overlapping perspectives: a) sociological/anthropological; b) economic; and c) 
policy processes. Few studies have looked at spatial changes and relationships over time, yet understanding how communities change physically offers insights to understanding the well-being of surrounding human populations that are dependent on fisheries.

In some past studies, researchers conducted qualitative research from an anthropological or sociological perspective, exploring changes in communities as fisherfolk face depleted stocks and increasing regulation (Krause and Glaser, 2003; Brookfield et al., 2005; Pettit et al., 2005; Stead, 2005). Some studies looked at changes in New England (Kaplan, 1998) and some specifically in New Bedford (Doeringer et al., 1986; Kaplan, 1999; Olson, 2006). Other studies have used quantitative economic data on the New England fishing industry to predict the short-term effects of reduced stocks (Moss and Terkla, 1985; Georgianna, 2000) or to critique regional fisheries management policy (Sutinen and Upton, 2000). Economic losses make a clear case for changing and improving management tools. Whether qualitative or quantitative, social or market oriented, physical (spatial) studies of change also provide an opportunity to better understand the extent of fisheries management impacts on communities, and to improve understanding between regulators and regulated entities.

Making connections between the tracking of spatial changes in communities and the social and economic implications of such tracking is important given what we know of the importance of the need for fisherfolk to understand, accept, and influence fisheries policy (Jentoft et al., 1998; Allison, 2001; Kaplan and McCay, 2004; Christensen et al., 2007). Indirectly, land use surveys and analyses can be cooperative research endeavors that foster improved relationships between stakeholders (resource users), scientists, and policymakers (Hartley and Robertson, 2006). These surveys involve tapping knowledge 
not only of fishermen, but of other members of the fishing community such as those geographically close to fishing infrastructure or who are involved in the operation of land-based support industries. Furthermore, examining the changes in waterfront land uses in ports in relation to commercial fishing activity - similar to looking at income and employment - will help planners and fisheries managers anticipate reactions to certain policies. Finally, considering broad effects, not just those on the pocket book, can improve co-management planning and institutional arrangements (Krause and Glaser, 2003; Rossiter and Stead, 2003; Stead, 2005; Luers et al., 2006; Olson, 2006).

Despite the knowledge that land uses are important indicators of economic wellbeing and the health and vitality of coastal communities, research exploring the relationship between marine fisheries and coastal land use change is sparse. Most literature that tracks land use changes, focuses on water quality impacts from run-off associated with land use cover (e.g., Basnyat et al., 1999), effects on near shore species biodiversity (e.g., Gordon, 2007), and on the development of marine aquaculture (e.g., Macfarlane, 2003). These are largely effects of land use on fisheries and they neglect inverse relationships.

Nevertheless, analyzing coastal land use patterns with social and economic data for fishing communities can provide insights about how changing fisheries conditions impact communities (Goodwin, 1988) and support for sustainable management policy (Krause and Glaser, 2003; Stead, 2005). This is related to the growing body of literature on trade, land use change, and biodiversity conservation (Polasky et al., 2004). Such research emphasizes the tradeoff between land use activities and habitat or species conservation and involves the consideration of social welfare in the context of utility 
maximization. Here we take a related approach starting with localized assumptions of individual landowner's utility that affects land use change/preservation decisions. Past studies have used similar assumptions in terrestrial applications (e.g., Parra-López et al., 2008). Our study is novel in its coastal land-marine application.

For local-level spatial and market analyses, a geographic information system (GIS) approach is recommended (Ballas and Clarke, 2000). The advantages of using GIS for terrestrial studies of land use change has been acknowledged for some time and is now increasingly used for marine and coastal applications (Stanbury and Starr, 1999) and for fisheries management (Webb and Bacon, 1999). GIS is especially appropriate for use in time series and local analyses (particularly when the spatial units are parcels) and when used in combination with statistical modeling of temporal coastal land use changes (e.g., Luers et al., 2006; Crawford, 2007).

\section{The Study Area - New Bedford/Fairhaven}

The New Bedford/Fairhaven Harbor is one of the most important U.S. commercial fishing ports. The harbor straddles the Acushnet River that flows into Buzzards Bay. The majority of the harbor-related businesses are in the City of New Bedford with a smaller portion in the Town of Fairhaven (see Figure 1). This reflects to some degree the larger, more developed and urban character of New Bedford.

The estimated population of New Bedford is 91,849 individuals, and the city has an area totaling approximately $52.4 \mathrm{~km}^{2}$. Fairhaven is much smaller, having an estimated population of 16,124 residents (U.S. Census Bureau, 2008) and a total area of approximately $32 \mathrm{~km}^{2}$. Most of the commercial fishing in the joint harbor is concentrated 
in New Bedford, whereas most of the marine service and vessel businesses are in Fairhaven (Vanasse Hangen Brustlin, 2002).

The New Bedford/Fairhaven area was selected as the study area due its prominence among East Coast and U.S. commercial fishing ports. Based on recent National Oceanic and Atmospheric Administration (NOAA) data, New Bedford is the number one fishing port in the United States in terms of ex-vessel revenue; here commercial fishing revenue totaled \$268 million in 2007 (NOAA, 2008b). Fisheries play an important role in the local economy, particularly in terms of employment (Table 1$){ }^{2}$ Historically, New Bedford is one of the most important U.S. ports. It is the birthplace of the whaling industry in the 1800s, and a leader in the fishing industry. The port is situated close to the rich Atlantic sea scallop and yellowtail flounder fishing grounds on Georges Bank and to the south. For the most part of recent decades, New Bedford has been the leading port in the United States in value of marine fisheries catch, mostly due to sea scallop landings (Georgianna, 2000). In 2006 and 2007, the total landings of all species were 76.3 and 67.8 million kilogram, valued at \$281.4 million and \$268.0 million (in current year dockside values), respectively (NOAA National Marine Fisheries Service, 2008b). Table 2 depicts the quantity and value of landings by the main species for the study period.

Data sources, particularly the spatial sources of information, are relatively organized and accessible for the parcels of interest in New Bedford and Fairhaven. For each town, we chose the boundaries of the study region to capture a relatively continuous area containing most of the parcels dedicated to uses of interest related to the active

\footnotetext{
${ }^{2}$ In Bristol County, Massachusetts almost all fishing related activities occur in the New Bedford area. The county's population was 545,379 in 2006.
} 
waterfront area and delimited by major geographic features (See Figure 1). For the New Bedford side, these features are the hurricane barrier at the entrance to the harbor in the south, the first major inland road in the west, and a major highway (I-195) in the north. On the Fairhaven side, the study area similarly includes those parcels related to the working waterfront. On this side, the northern and southern boundaries are two major marinas; the eastern (longitudinal) boundary encompasses one block landward of the first roadway so as to capture any parcels containing marine-related activities that may support the frontline waterfront parcels. Outside of these boundaries, parcels are almost exclusively non-marine related. The study area in New Bedford is much larger (1.04 $\left.\mathrm{km}^{2}\right)$ than the Fairhaven study area $\left(0.26 \mathrm{~km}^{2}\right)$. These areas constitute approximately $2 \%$ and $0.8 \%$ of the total areas of New Bedford and Fairhaven, respectively.

\section{Methods}

In this section, we describe a probability model of waterfront land use that provides a basis for evaluating the relationship between the abundance of fish stocks and marine-related land use changes. Generally, land use decisions are driven by profitability. In a standard bioeconomic analysis (Clark 1976), profit from fishing at time $t$ is $P h-c E$; where $P$ is the price of fish, $h$ is harvest, $c$ is the unit cost of fishing effort (E). Fish harvest $h=q E X$, where $q$ is the catchability coefficient and $X$ is the fish stock. Although profitability is influenced by several variables, fish stock $(X)$ is a key driver in that it not only affects short-term profitability but also determines the sustainability of the industry or long-term profitability. This is especially true when fishery stocks are depleted (i.e., $X$ is at relatively low level), since fish stock is a precondition for the existence of the fishing industry. 
Since fish stock is considered an indicator of long-term profitability in fishing, land use decisions can be significantly influenced by the stock level, rather than shortterm profitability. Thus, the probability of an individual parcel being used for a specific marine industry operation is a function of factors such as fish population stock sizes and parcel characteristics. In this case, the phenomenon modeled is discrete rather than continuous. Suppose that individual parcel owner's utility function can be written

$$
U\left(y_{i}, s\right)=u\left(y_{i}, s\right)+\varepsilon_{i}
$$

where $u$ is the measurable component of utility, $i$ is the land use option, $y$ is profit from the use, $s$ is the parcel's characteristics, and $\varepsilon$ is the random component. Following the usual random utility specification (Hanemann, 1984; Opaluch et al., 1993), the owner would choose a marine use option $i$ over a non-marine use option $j$ if

$$
u\left(y_{i}, s\right)+\varepsilon_{i}>u\left(y_{j}, s\right)+\varepsilon_{j}
$$

The probability to choose option $i$ is

$$
p_{i}=\operatorname{Prob}(\eta<\Delta u)=F(\Delta u)
$$

where $F(\bullet)$ is the cumulative distribution function (c.d.f.) of $\eta=\varepsilon_{j}-\varepsilon_{i}$ and $\Delta u=u_{i}-u_{j}$. A simple way of representing the dependence of probability $p_{i}$ on $\Delta u$ is to choose the logistic c.d.f. $\Lambda^{3}$ for $F(\bullet)$ :

$$
p_{i}=\Lambda(\Delta u)=\frac{e^{\Delta u}}{1+e^{\Delta u}}
$$

Generally, the utility difference may be modeled as

$$
\Delta u=\beta^{\prime} x
$$

\footnotetext{
${ }^{3}$ For a discussion of the logit regression model, see Cox (1970) and Greene (1997).
} 
where $x$ is a set of explanatory variables and $\beta$ is a set of corresponding parameters reflecting the impact of a change in $x$ on the probability $p_{i}$.

From (2), an individual land owner's utility $u_{i}$. is a function of income $y$ from the use option $i$, and the parcel's characteristics $s$. For fishery-related industries, $y$ is affected by marine resource conditions. Thus, in the analyses of marine land use probability, the explanatory variables $x$ included fishery stock size, parcel size, township and regulatory status (as described below). The relationship between stock size and the probability associated with a marine use $p_{i}$ was expected to be positive: larger stock sizes are associated with higher income when a parcel is used for marine-related activities, ceteris paribus. The expected signs of other variables were unclear.

\section{Data}

The data collection phase had two sub-phases: 1) spatial database development, and 2) collection of resource indicators and industry data. The former is primary data, collected for the purposes of this study. The latter are secondary data collected mostly from government agencies such as the National Marine Fisheries Service.

\subsection{Spatial Land Use Data}

The principal sources of available spatial data are: (a) licenses issued by the Massachusetts Waterways Regulation Program (MWRP); (b) assessors’ data (e.g., ownership information); (c) master planning and harbor planning documents; and (d) other state and local records (e.g., the registry of corporations and building inspection documents). The MWRP is a state-level regulatory program that has as its goals preservation of water-dependent uses of coastal properties and of public use rights for “fishing, fowling and navigating” (Portman, 2006). Assignment of land uses depended on 
finding some evidence of a particular activity listed in one of the above four types of source documents or on indications given by key informants. We collected historical information about land use activities and on changes in land uses from city and harbor development officials and from members of the community familiar with the waterfront by displaying and discussing sets of maps indicating land uses for different periods. The use of several sources of cross-referenced information helped validate classifications. The assessor's records ended up being the major source of data in New Bedford. In Fairhaven with a small number of study parcels, key informants served as the main source of land use information.

We tracked land use definitions in a spatial database using GIS (ArcMap 9.2). The GIS software facilitated calculation of the area dedicated to each use. Double or triple counting of area dedicated to a use could occur because up to three uses were recorded for each parcel. We determined the land uses of interest to be: fishing, processing, repair, transport, and boating (see Table 3). The categorization of these land uses as marine-related was based on our observations and was similar to the categories used by Pontecorvo et al. (1980). ${ }^{4}$ In New Bedford in 2006, 59\% of the study area consisted of parcels dedicated to at least one of these activities.

'Fishing' refers to parcels that provided docking and tie-up facilities for nonrecreational, commercial fishing vessels. We included only upland, filled, or pilesupported structures in this category. 'Processing' included anything described (by any of the information sources) as a fish plant, or fish or seafood processing establishment.

\footnotetext{
${ }^{4}$ Pontecorvo et al. (1980) used supply-side and demand-side criteria to categorize ocean and non-ocean businesses. These include extractive and spatial criteria in which the primary activity of the establishment involves extraction of living or inanimate objects from the ocean, utilizes ocean water as a significant element in the production process, or involves some manner of transportation of passengers, cargo, natural resources, or electrical impulses upon or below the ocean surface. Demand-side criteria are either complementary or geographic - either a significant portion of the establishment's output is attributable to the ocean or the establishment is located within a region proximate to the ocean.
} 
'Repair' consisted of retail establishments selling vessel parts, vessel service, and/or machine and service shops that due to their proximity to the harbor most likely serviced seafaring vessels. An example is a welding shop. 'Transport' included any use related to transit of goods or passengers plus adjacent packaging facilities, storage of goods for transport, and cold storage. Lastly, 'boating' included land areas adjacent to marinas, recreational boat storage lots, parks with boat ramps, and tie-up areas if these accounted for a significant portion of a parcel. As with commercial fisheries docking, 'boating' included only upland, filled pile-support structures, and only those that were used for business purposes (as opposed to floats, docks, and ramps associated with residential properties).

In addition to size and township, a variable indicates whether the parcel is within or outside of the New Bedford/Fairhaven Designated Port Area (hereafter: the DPA). In 1978 the Massachusetts Office of Coastal Zone Management created designated port areas (DPAs) in order to encourage use of coastal resources in a manner that is consistent with the federal Coastal Zone Management Act of 1972. There are 11 DPAs throughout Massachusetts which are implemented as overlay districts (bounded zones). ${ }^{5}$ DPA regulations promote water dependent marine industrial uses along working waterfronts. The rationale behind these regulations is that non-marine industrial uses have a far greater range of location options; there is a desire on the part of policy makers to preserve these use areas along important harbors and ports, the loss of which is considered in some cases to be irreversible (Donovan, 2003). Whether or not parcels with marine-related uses are within the DPA is an indication of the effectiveness of this regulatory program.

\footnotetext{
${ }^{5}$ Other DPAs are in Gloucester, Salem, Beverly, Lynn, Mystic River, Chelsea Creek, East Boston, South Boston, Weymouth/Fore River, and Fall River/Mt. Hope Bay.
} 


\subsection{Marine Resource Indicators}

Marine resource conditions are represented by species abundance indices compiled by the Northeast Fisheries Science Center of the National Marine Fisheries Service (NMFS). NMFS collects data for 62 finfish and invertebrate species stocks in cooperation with other federal and state agencies and academic institutions. Species abundance is represented by estimates of species biomass. NMFS has conducted an extensive bottom trawl survey program off the northeastern United States for more than 40 years to monitor species abundance and biomass trends. Trawl surveys are conducted bi-annually in spring and fall. For principal groundfish, pelagics and elasmobrachs, an aggregate biomass index was computed as the sum of the individual species' stratified mean catch per tow values, smoothed (LOESS smoother using 20 percent of the data) to account for inter-annual variability (NOAA National Marine Fisheries Service, 2008a). There are separate dedicated surveys conducted for sea scallops, and for surfclams/ocean quahogs using different gear and in areas specific to these species. For this study, abundance indices of seven grouped categories of species, which overall combine some 28 types of marketable fish and shellfish, were used in regression analyses.

\subsection{Study Time Period}

The period studied was limited to 1986-2006 because of the limited availability of data for both land use changes (explained in Section 7 below) and the fisheries industry. Due to difficulties identifying the exact year of a land use change, we developed snapshots of five-year periods. Land uses were defined according to activities taking place on a parcel during or up to the last year of a 5-year period. This provided a total of four periods (1986-1990; 1991-1995; 1996-2000; 2001-2006) spanning 21 years. For 
consistency, the statistical modeling also used means for each of the four periods for relevant variables, such as species relative abundance.

For each of the four periods, information was obtained on 165 parcels in New Bedford and 193 parcels in Fairhaven for a total of 1,426 observations over the 1986-2006 period. Over the past two decades, there has been a slow but steady increase in marine industry related land use in the study area. During the 21-year study period, parcels used for commercial fishing increased from 20 to 24, seafood processing from 40 to 54, marine supply and repair from 29 to 36, commercial fishing from 20 to 24, and recreational boating from 14 to 19 (Table 3). Figure 2 illustrates the changes in the number of marine use parcels by period, as well as the average sea scallop survey abundance index and average annual sea scallop landings during each of these periods. Note that the Atlantic sea scallop fishery has been the most important fishery in the area. Other researchers have pointed out the importance of this species in the region (Repetto, 2001; Edwards, 2002; Baskaran and Anderson, 2005) and particularly for the New Bedford fishing sector (Olson, 2006).

The specific measurements and descriptive statistics of variables used in the land use probability model estimations are listed in Table 4. The five marine uses account for $31 \%$ of the total parcels in the study area. The average sea scallop survey biomass index during the study period is $3.03 \mathrm{~kg}$ (meats)/tow. The size of waterfront parcels range from 30 to 41,000 square meters with an average of 3,600 square meters. In the regression analyses discussed below, a log-scaled area variable was used to achieve improved model results. Forty six percent of the parcels are within the DPA overlay. 
In addition to the above variables, data on commercial fish landings (quantity and value), employment in different marine industries, and commercial fishing vessel counts were also compiled and examined. These explanatory variables were excluded from the final regression analyses because they were collinear with the stock variable and as such their inclusion does not provide additional information.

\section{Results}

The land use choice model described was developed using the parcel-level land use data, parcel characteristics, marine resource stock data, and the logistic regression procedure available within the SAS statistical software package. We ran separate models for each marine use category and combined marine uses. Generally, marine resource condition alone is not a determinant strong enough to influence land use choice for four of the five individual marine use categories, except seafood processing. However, the stock variable is a significant factor in determining cumulative marine land use among different marine uses categories.

As discussed below, eight models were estimated to address different concerns related to marine industry classification, location, land use regulation, and data issues. Table 5 presents logistic regression estimates of marine land use probability for four representative model applications. The results indicate that the models fit the data well. For example, for Model I the likelihood ratio statistic is 306.05, well above the 11.34 critical value for significance at the 0.01 level for 3 degrees of freedom. As expected, the sign for the scallop stock coefficient is positive. The sign of the (parcel) area coefficient is also positive. The area variable is highly significant with p-values less than or equal to 0.01 in almost all cases. For this set of models, the scallop stock serves appropriately as 
an indicator species. Scallops make up on average between 28\% (1996-2000) and 60\% (1986-1990) of the live weight landed and between 47\% (1996-2000) and 66\% (20012006) of the value of all species landed over the four time periods (see Table 2). The scallop stock variable is significant at the $5 \%$ level in Models I, III and IV; and at the 10\% level in Model II.

The results of Model I suggest that an increase in scallop stock is associated with an increase in marine use probability. The probability is greater when a waterfront land parcel is larger. For the same parcel characteristics and stock conditions, the marine use probability is lower if the parcel is located in Fairhaven.

Model II is the same as Model I except that recreational boating ("boating”) was excluded from the marine land use definition (and therefore labeled “Marine 4” which refers to four marine related land use activities described in Section 5.1 instead of the full five). While the relationships among fishing, processing, repair, and transport are largely complementary, the relationship between recreational boating and the fishing industry is more complex and could be competitive in some cases. For example, commercial fishing boats may compete with recreational boats for dock space when the fishery is in decline and vessels are tied up for long periods (Goodwin, 1988). The results of Model II are consistent with those of Model I, suggesting that our main results are robust with respect to changes in marine-related land use classification (i.e., dependent variable specifications).

Since most DPA parcels are located in New Bedford, the DPA variable is highly correlated with the township variable, therefore Model III assesses the effects of the DPA with regard to the land use probability, excluding the township variable (i.e., Fairhaven). 
The results indicate that the marine land use probability is significantly greater if a parcel is located in the DPA suggesting that this regulatory program is effective.

Model IV evaluates the effects of lagged land use. If a parcel was employed in a marine related activity 5 years ago, it would be more likely to be employed in a marine related activity today, due to adjustment costs or asset fixity. This hypothesis is fully supported by the statistically significant coefficient for the lagged land use variable.

Given that New Bedford is the core area of the commercial fishing industry, a second set of models (Models V-VIII) was estimated for parcels in New Bedford only (see Table 6). The results are consistent with those of Models I through IV. The effects of the sea scallop stock indicator variable are more significant for New Bedford than for the wider area affirming the more dominant role played by the New Bedford area in seafood processing in New England. The results of Model VI clearly indicate the effects of marine resource conditions on the processing industry in the study area. With parcels in New Bedford and eliminating the effect of township, the DPA variable is highly significant in Models V and VII again suggesting the effectiveness of this land use regulation.

Finally, we develop a sensitivity analysis with respect to the stock variable. Besides scallops, there are significant groundfish and monkfish landings in the study area (see Table 2). Over the four time periods, principal groundfish make up between $7.5 \%$ (2001-2006) and 22\% (1986-1990) of the live weight landed and between 17\% (20012006) and 34\% (1986-1990) of the value landed. Monkfish make up between 2.5\% (2001-2006) to 8\% (1991-1995) of live weight landed and between 3\% (1986-1990) and $11 \%(1996-2000)$ of the value landed. Of note is that scallops, groundfish and monkfish 
together make up between 43\% (1996-2000) to 86\% (1986-1990) of the average live weight landed and between 81\% (1996-2000) and 88\% (1986-1990) of the average total value landed for the time periods studied.

As shown in Table 7, Model I was re-estimated separately using three different stock variables: groundfish abundance index (Model IX), monkfish abundance index (Model X), and the sum of abundance indices for groundfish, monkfish, and scallops (Model XI). Both the goundfish and the 3-species stock variables are statistically significant; and the monkfish stock variable is also close to $10 \%$ significant. The results indicate that our overall model results are robust.

In summary, land use choice probability is primarily influenced by marine resource conditions, parcel size, location (township), regulation, and land use in the previous period. A waterfront parcel is more likely to be used for marine purposes when fishery resource conditions are good, if its area is large, if it is in New Bedford, if it is in the Designated Port Area, and if it was previously employed in marine use, and vice versa.

Although the sign of an estimated logit coefficient suggests either an increase or decrease in likelihood of a marine use, the coefficient itself does not measure the correct marginal probability effect for non-zero observations of the dependent variable. Estimates of correct marginal probability effects can be derived utilizing the estimated coefficients and the following equation (see Equation (4); Greene, 1997): 


$$
\frac{\partial \Lambda\left(\beta^{\prime} x\right)}{\partial x}=\Lambda\left(\beta^{\prime} x\right)\left[1-\Lambda\left(\beta^{\prime} x\right)\right] \beta
$$

The marginal effects based on Models IV and V results are listed in the last column of Tables 5 and 6, respectively.

An increase in the scallop stock by one kg/tow is associated with an increase in marine use probability by $1.55 \%$ in the entire study area (Table 5) and by $2.14 \%$ in New Bedford alone (Table 6). Figure 3 depicts the change in marine land use probability with respect to changes in the sea scallop survey biomass index using Model IV. As the stock index rises from 2 to $10 \mathrm{~kg} /$ tow, the probability increases from $17 \%$ to $32 \%$, respectively. Otherwise using Model IV, the marginal effect of the natural logarithm of area suggests that marine use probability rises on average by $4.31 \%$ when the log-scaled area measure is increased by one unit. Among categorical (or dummy) variables, a parcel in Fairhaven has a reduced probability of $6.92 \%$ to be used for marine-related operations, compared with parcels in New Bedford (Table 5). A parcel in the DPA has an increased probability of 18.63\% to be used for marine-related operations. Finally, a parcel with previous marine uses has an increased probability of $80.75 \%$ to be used for marine-related operations (Table 5).

\section{Limitations}

Some limitations to the methodology relate to the vagaries of the data sources; others relate more broadly to the chosen spatial characterization (unit) and how policies and human nature encourage or inhibit waterfront land use change. The methodology may be limited in its ability to capture these factors.

Assessors’ records are limited because in both New Bedford and Fairhaven records are available only back to the mid 1980s. Also, assessors' records that focus on 
the sale and purchase of land, do not always give a good indication of use. Waterways Regulations Program (Chapter 91) licenses limited data collection on land use change for several reasons. First, regulations that require the issuance of new or amended licenses when uses of a property change have only been in effect since 1984 and licenses issued before that year usually do not include a use statement. Secondly, Chapter 91 licenses are issued for existing uses that require repairs, slight changes, or require a license renewal. In these cases, the license does not usually indicate when the activity of interest began on that site. Furthermore, Chapter 91 licenses can also indicate intent and not implementation. Although regulators granted approval, the licensee may never have implemented the licensed uses. Finally, because Chapter 91 regulations require a new or amended license whenever uses change, property owners include very broad use statements in their license applications so as to avoid the need for re-licensing. Despite these limitations, Chapter 91 licenses give a further indication of existing uses, of abutting uses, and of some changes for those properties that are within program jurisdiction (Portman, 2006).

Key interviewees proved to be an excellent source of spatial information. However, limitations resulted from memory lapses and difficulty disassociating what interviewees saw in maps showing recent orthophotos as background from previous uses on the property. Another problem is that some city officials interviewed, especially those who had only been living and working in the area for a short time, tended to focus on the future in their work rather than the past and therefore could not contribute much to tracking historical uses. 
Other sources of spatial data include the Massachusetts state GIS office (MassGIS) shape file of historical land uses, historical orthophotos, pictometry, and other types of aerial imaging that show physical structures on waterfront properties. In general, the categories of land uses in the MassGIS database are very general and polygons are taken from zoning and other sources that do not match municipal parcel polygons. It is difficult to discern exact uses from aerial imaging. Such images, including orthophotos and pictometry visuals, are inconsistently available throughout Massachusetts, are taken from different periods, in different geographical areas, and use different technologies and standards resulting in varying image resolution and clarity.

Other methodological limitations relate to the significance of the data and the effectiveness of capturing change. Parcels can be an inaccurate unit of analysis. Although they provide a good way to track land use changes on the local level, they are somewhat arbitrary units because their size relates to property conventions, real estate market forces, and relic policies related to historical zoning patterns. Problems can arise when it is unclear how much of the parcel is dedicated to a particular land use. Large parcels such as those for marine construction yards, large wharfs, and shipyards, may skew the data in their favor over other uses, such as non-marine residential properties and offices which are generally on smaller parcels. Furthermore, parcel size gives no indication of intensity of use. Some fisherfolk have pointed out that the number of hours a site is active, including nighttime hours, is important.

The land use choice model is simplified in that it does not fully account for the tendency for properties to maintain marine-related uses. This is especially important in 
New Bedford, where in addition to the state-level DPA overlay local regulatory constraints restrict the loss of certain marine-related land uses and discourage change. ${ }^{6}$

\section{Discussions and Conclusions}

Since the early 1980s, there have been dramatic shifts in species abundance and harvesting capacity in many New England marine fisheries, accompanied by subsequent increases in regulation (e.g., area closures and limits on days at sea). Based on the neoclassical concept of utility, industry participants seek to adjust to new resource conditions to lessen adverse financial impacts and to maximize utility under these dynamic conditions. Logistic regression models developed to assess the impact of changing marine resource and harvesting conditions on coastal land uses suggest that species abundance changes influence the location of associated marine-related activities.

The main result of our study indicates that a significant relationship exists between major fisheries stock conditions and waterfront land uses, although land use decisions are influenced by many complex market and regulatory factors. The results suggest that the cumulative effect of marine resource conditions can substantially alter marine industry’s location decisions and may have long-term and multi-sector impacts at the community level. This is an important point for agencies charged with decisionmaking regarding coastal land use planning, the protection of fisheries infrastructure, and stock management.

\footnotetext{
${ }^{6}$ Following publication of the 2002 New Bedford/Fairhaven Harbor Plan, the City of New Bedford promulgated the Supporting Designated Port Area Use Eligibility Credit Program. Through this program, the New Bedford Harbor Development Commission seeks to ensure that the development of commercial uses upon filled tidelands within the harbor that will provide direct economic or operational support to water-dependent industrial uses (Vanasse Hangen Brustlin, 2002).
} 
Federal laws such as the National Environmental Policy Act of 1969 and the Sustainable Fisheries Act of 1996 require that conservation and management measures take into consideration the importance of fishery resources to fishing communities, with the goals of providing for the sustained participation of those communities and minimizing adverse economic impacts. One of the challenges in gauging the long-term and cumulative impacts of management regulations on coastal fishing communities has been the lack of clear understanding of the interactions between changes in fish stocks and waterfront land uses. Results of this analysis provide a high-resolution depiction of these interactions.

Further research is needed to expand on these findings. Regulatory changes, both in terms of restrictions on fishing to allow stock recovery and in terms of land use change controls, should be more specifically explored. A significant portion of the New Bedford/Fairhaven Harbor falls within the DPA, one of eleven throughout the state, where change from marine industrial land use is restricted. Based on this study such a restriction is quite effective. For purposes of comparison it would be helpful to contrast probabilities of land use change to similar study areas without DPA status.

Coastal fishing towns are continually adapting to changing resource conditions as reflected in the spatial structure of their communities. It would be interesting to examine the extent of such relationships in minor fishing ports possessing less peripheral long-term infrastructure than in New Bedford and Fairhaven. In any case, this study highlights that regulators and policymakers concerned with protecting marine related uses in coastal communities should not neglect the importance of rebuilding and maintaining fishery resources and vice versa. 


\section{Acknowledgements}

This research was supported by the National Atmospheric and Oceanic Administration (NOAA) through the WHOI/NOAA Cooperative Institute on Climate and Ocean Research (CICOR) under award number NA17RJ1223 and by the Marine Policy Center of the Woods Hole Oceanographic Institution. The authors are also grateful for the comments of Fred Serchuk of NOAA’s National Marine Fisheries Service and two anonymous reviewers. 


\section{References}

Allison, E. H., 2001. "Big Laws, Small Catches: Global Ocean Governance and the Fisheries Crisis." Journal of International Development, 13: pp. 933-950.

Ballas, D. and Clarke, G., 2000. "GIS and microsimulation for local labour market analysis." Computers, Environment and Urban Systems, 24(4): pp. 305-330.

Baskaran, R. and Anderson, J. L., 2005. "Atlantic sea scallop management: an alternative rights-based cooperative approach to resource sustainability." Marine Policy, 29(4): pp. 357-369.

Basnyat, P., Teeter, L. D., Flynn, K. M. and Lockaby, B. G., 1999. "Relationships Between Landscape Characteristics and Nonpoint Source Pollution Inputs to Coastal Estuaries." Environmental management, 23(4): pp. 539-549.

Brookfield, K., Gray, T. and Hatchard, J., 2005. "The concept of fisheries-dependent communities: A comparative analysis of four UK case studies: Shetland, Peterhead, North Shields and Lowestoft." Fisheries Research, 72(1): pp. 55-69.

Christensen, A.-S., Raakjaer, J. and Olesen, T., 2007. "The voices of Danish fishermen in resource management -- An examination of the system of negotiated economy." Ocean \& Coastal Management, 50(7): pp. 551-563.

Clark, C.W., 1976. Mathematical Bioeconomics: The Optimal Management of Renewable Resources. New York: John Wiley \& Sons.

Cox, D. R., 1970. The Analysis of Binary Data. New York, NY: Chapman and Hall.

Crawford, T. W., 2007. "Where does the coast sprawl the most? Trajectories of residential development and sprawl in coastal North Carolina, 1971-2000." Landscape and Urban Planning, 83(4): pp. 294-307.

Doeringer, P. B., Moss, P. I. and Terkla, D. G., 1986. The New England Fishing Economy: Jobs, Income, and Kinship. Amherst, MA: The University of Massachusetts Press.

Donovan, D., 2003. "Designated Port Areas: Flexible Protection for a Finite Resource." Coastlines, Summer issue: p. 27.

Edwards, S., 2002. "Rent-Seeking and Property Rights Formation in the U.S. Atlantic Sea Scallop Fishery." Marine Resource Economics, 16: pp. 263-275.

Food and Agriculture Organization, 2006. "The State of World Fisheries and Aquaculture", Rome, Food and Agricultural Organization of the United Nations. 
Georgianna, D., 2000. "The Massachusetts Marine Economy", Dartmouth, MA, University of Massachusetts Donahue Institute, Center for Policy Analysis. pp 54.

Goodwin, R. F., 1988. Fishports: Service Centers for a Changing Industry. In Urban Ports and Harbor Management: Responding to Change along U.S. Waterfronts. M. J. Hershman (ed.). New York, NY: Taylor \& Francis: 173-194.

Gordon, I. J., 2007. "Linking land to ocean: feedbacks in the management of socioecological systems in the Great Barrier Reef catchments." Hydrobiologia, 591(1): pp. 25-33.

Greene, W. H., 1997. Econometric Analysis. Upper Saddle River, NJ: Prentice Hall.

Hanemann, W. M., 1984. "Welfare evaluations in contingent valuation experiments with discrete responses." American Journal of Agricultural Economics, 66(3): pp. 332341.

Hartley, T. W. and Robertson, R. A., 2006. "Stakeholder Engagement, Cooperative Fisheries Research and Democratic Science: The Case of the Northeast Consortium." Human Ecology Review, 13(2): pp. 161-171.

Hennessey, T. and Healey, M., 2000. "Ludwig's ratchet and the collapse of New England groundfish stocks." Coastal Management, 28(3): pp. 187-213.

Hershman, M. J., Ed. 1988. Urban Ports and Harbor Management: Responding to Change along U.S. Waterfronts. New York, NY: Taylor \& Francis.

Jentoft, S., McCay, B. J. and Wilson, D. C., 1998. "Social theory and fisheries comanagement." Marine Policy, 22(4-5): pp. 423-436.

Kaplan, I. M., 1998. "Regulation and compliance in the New England Conch Fishery: A case for co-management." Marine Policy, 22(4-5): pp. 327-335.

Kaplan, I. M., 1999. "Suspicion, growth and co-management in the commercial fishing industry: the financial settlers of New Bedford." Marine Policy, 23(3): pp. 227241.

Kaplan, I. M. and McCay, B. J., 2004. "Cooperative research, co-management and the social dimension of fisheries science and management." Marine Policy, 28(3): pp. 257-258.

Krause, G. and Glaser, M., 2003. "Co-evolving geomorphical and socio-economic dynamics in a coastal fishing village of the Braganca region (Para, North Brazil)." Ocean \& Coastal Management, 46(9-10): pp. 859-874. 
Luers, A. L., Naylor, R. L. and Matson, P. A., 2006. "A case study of land reform and coastal land transformation in southern Sonora, Mexico." Land Use Policy, 23(4): pp. 436-447.

Macfarlane, S. L., 2003. "Shellfish restoration: It's not just biology that matters." Journal of Shellfish Research., 22(1): p. 342.

Minnesota IMPLAN Group, 2000. IMPLAN Professional Version 2: User’s Guide, Analysis Guide, and Data Guide. Stillwater, Minnesota.

Moss, P. and Terkla, D., 1985. "Income and Employment Change in the New England Fishing Industry." Ocean Development and International Law, XV(1): pp. 37-59.

NOAA National Marine Fisheries Service, 2008a. "Status of Fishery Resources off the Northeastern US: Aggregate Resource and Landings Trends." 2008, http://www.nefsc.noaa.gov/sos/agtt/. Accessed: September 4, 2008.

NOAA National Marine Fisheries Service, 2008b. "Fisheries of the United States 2007." Current Fishery Statistics No. 2007, 103 pp.

Olson, J., 2006. "Changing Property, Spatializing Difference: The Sea Scallop Fishery in New Bedford, Massachusetts." Human Organization, 65(3): pp. 307-318.

Opaluch, J. J., Swallow, S. K., Weaver, T., Wessells, C. W. and Wichelns, D., 1993. "Evaluating impacts from noxious facilities: including public preferences in current siting mechanisms." Journal of Environmental Economics and Management 24(1): pp. 41-59.

Parra-López, C., Groot, J. C. J., Carmona-Torres, C. and Rossing, W. A. H., 2008. "Integrating public demands into model-based design for multifunctional agriculture: An application to intensive Dutch dairy landscapes." Ecological Economics, 67(4): pp. 538-551.

Pettit, S. J., Gardner, B. M., Marlow, P. B., Naim, M. M. and Nair, R., 2005. "Exseafarers shore-based employment: the current UK situation." Marine Policy, 29(6): pp. 521-531.

Polasky, S., Costello, C. and McAusland, C., 2004. "On trade, land-use, and biodiversity." Journal of Environmental Economics and Management, 48(2): pp. 911-925.

Pontecorvo, G., Wilkinson, M. and Holdowsky, M., 1980. "Contribution of the ocean sector to the United States economy." Science, 208: pp. 1000-1006. 
Portman, M., 2006. "Tidelands Management: Implementation of the Massachusetts Public Waterfront Act." Journal of Environmental Policy and Planning, 8(4): pp. 293-308.

Repetto, R., 2001. "A natural experiment in fisheries management." Marine Policy, 25(4): pp. 251-264.

Rossiter, T. and Stead, S., 2003. "Days at sea: from the fishers' mouths." Marine Policy, 27: pp. 281-288.

Stanbury, K. B. and Starr, R. M., 1999. "Applications of Geographic Information Systems (GIS) to habitat assessment and marine resource management." Oceanologica Acta, 22(6): pp. 699-703.

Stead, S. M., 2005. "Changes in Scottish coastal fishing communities - Understanding socio-economic dynamics to aid management, planning and policy." Ocean \& Coastal Management, 48(9-10): pp. 670-692.

Sutinen, J. and Upton, H., 2000. "Economic perspectives on New England fisheries management." Northeastern Naturalist, 7(4): pp. 361-372.

U.S. Census Bureau, 2008. "Population Finder." http://www.census.gov/. Accessed: October 1, 2008.

Vanasse Hangen Brustlin, 2002. "New Bedford/Fairhaven Harbor Plan", City of New Bedford and Town of Fairhaven. pp 178.

Webb, A. D. and Bacon, P. J., 1999. "Using GIS for catchment management and freshwater salmon fisheries in Scotland: the DeeCAMP project." Journal of Environmental Management, 55(2): pp. 127-143. 
Figure 1. Locus Map of New Bedford and Fairhaven

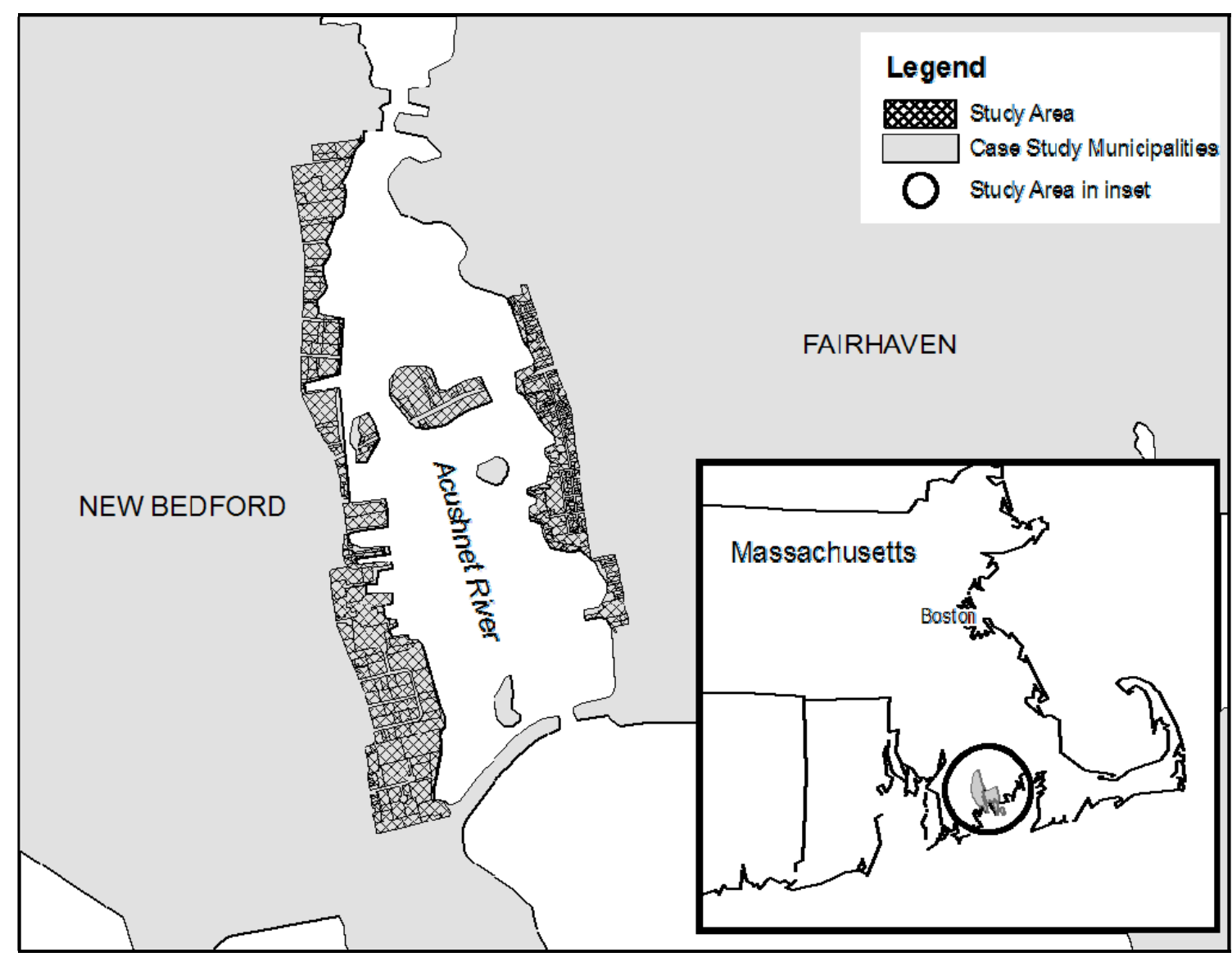


Figure 2. Marine Resource Condition and Marine Land Use (Parcel Count)

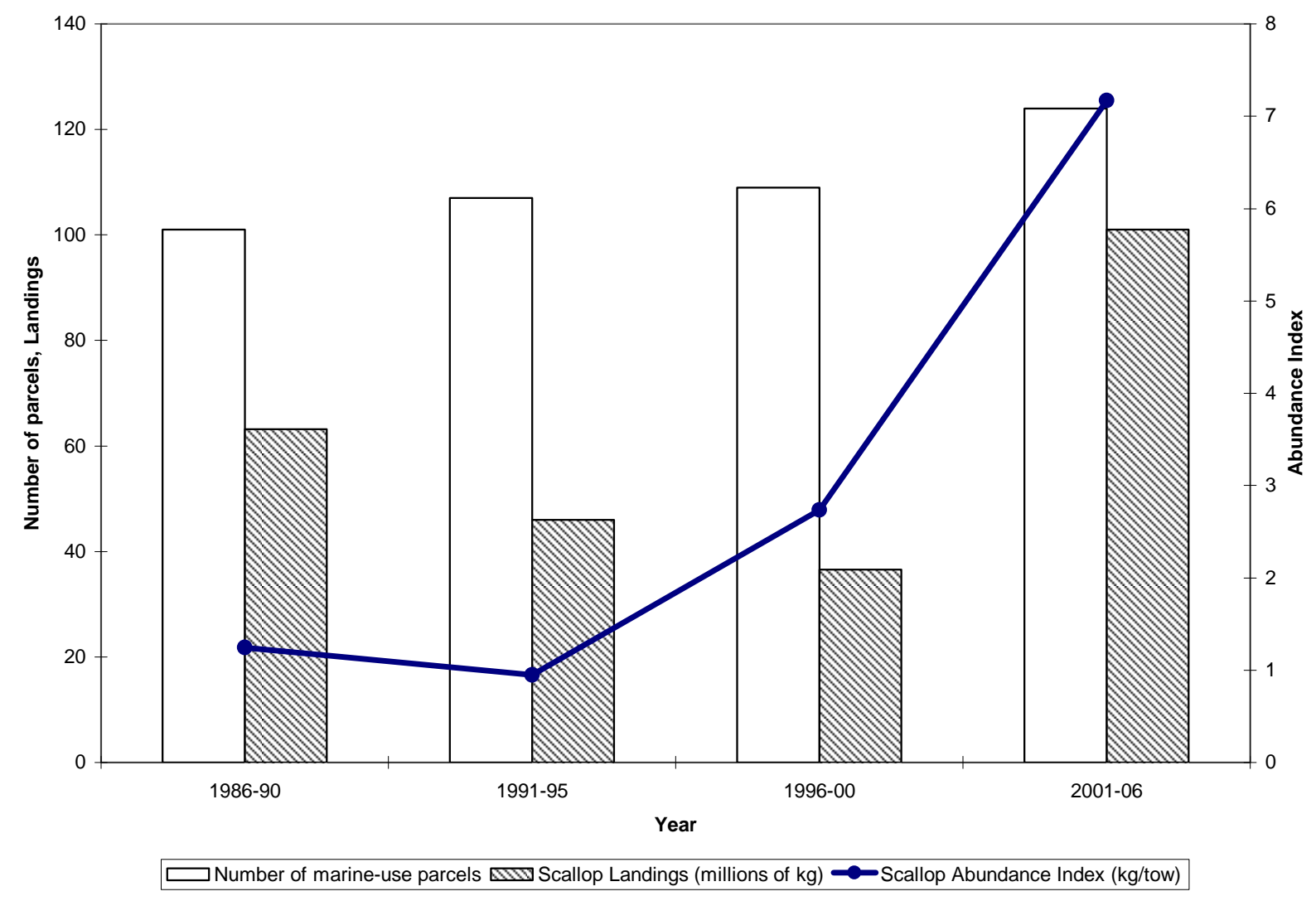


Figure 3. Marine Resource Condition and Marine Land Use Probability (using Model IV)

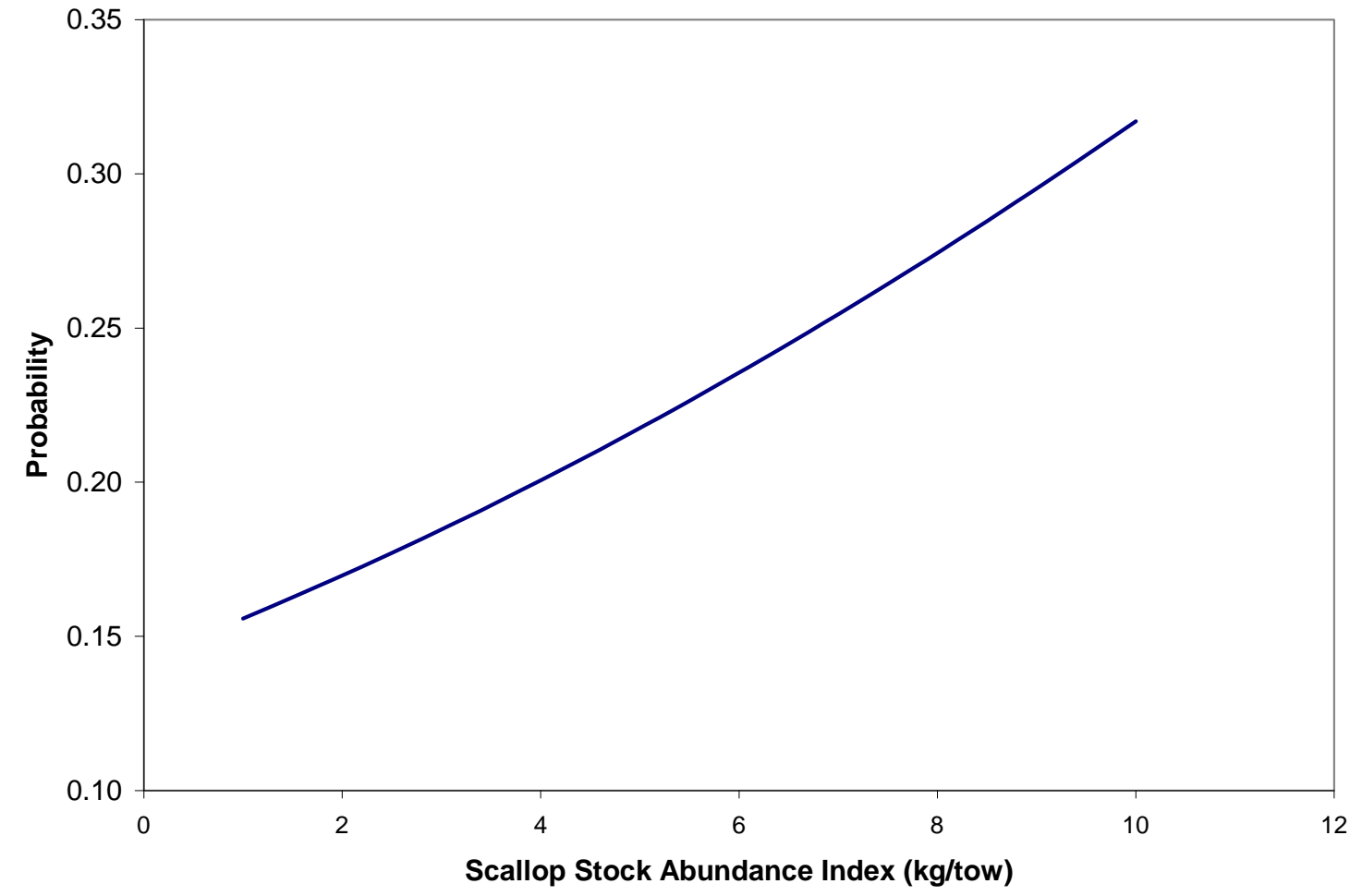


Table 1: 2006 Bristol County Output, Value Added, and Employment

\begin{tabular}{|c|c|c|c|c|c|}
\hline $\begin{array}{l}\text { Broad } \\
\text { Industry }\end{array}$ & $\begin{array}{l}\text { IMPLAN } \\
\text { Sector }\end{array}$ & $\begin{array}{c}\text { IMPLAN } \\
\text { Code }\end{array}$ & Output $^{\dagger}$ & $\begin{array}{c}\text { Value } \\
\text { Added }^{\dagger}\end{array}$ & Employment $^{\ddagger}$ \\
\hline \multirow[t]{2}{*}{ Fisheries } & Fishing & 16 & 290 & 170 & 4,957 \\
\hline & Seafood product preparation and packing & 71 & 336 & 49 & 1,194 \\
\hline \multirow[t]{2}{*}{ Shipbuilding } & Ship building and repairing & 357 & 38 & 14 & 211 \\
\hline & Boat building & 358 & 8 & 2 & 35 \\
\hline Shipping & Water transportation & 393 & 20 & 3 & 45 \\
\hline \multicolumn{2}{|l|}{ County Totals } & & 33,301 & 18,138 & 261,092 \\
\hline \multicolumn{2}{|c|}{$\%$ of marine sector total to county total } & & $2.08 \%$ & $1.31 \%$ & $2.47 \%$ \\
\hline
\end{tabular}

\footnotetext{
† \$U.S. millions (2006)
}

${ }^{\ddagger}$ Number of employees 
Table 2. New Bedford-Fairhaven Quantity and Value of Fish Landed

\begin{tabular}{|c|c|c|c|c|c|c|c|c|c|c|}
\hline Year & $\begin{array}{l}\text { Principal } \\
\text { Groundfish }\end{array}$ & Scallops & Monkfish & Clams & Whiting & $\begin{array}{l}\text { Elasmo- } \\
\text { branchs }\end{array}$ & Pelagics & $\begin{array}{l}\text { Inverte- } \\
\text { brates }\end{array}$ & Others & Total \\
\hline & & \multicolumn{9}{|c|}{ Annual Average Live Weight in Thousands of Kilograms } \\
\hline 1986-1990 & 23,513 & 63,224 & 4,166 & 5,354 & 5 & 1,316 & 177 & 570 & 7,535 & 105,860 \\
\hline 1991-1995 & 15,102 & 45,989 & 7,737 & 2,724 & 141 & 7,207 & 130 & 476 & 15,395 & 94,899 \\
\hline 1996-2000 & 10,756 & 36,550 & 8,302 & 1,230 & 137 & 5,751 & 634 & 1,311 & 65,484 & 130,156 \\
\hline \multirow[t]{2}{*}{ 2001-2006 } & 15,270 & 100,983 & 5,055 & 4,710 & 1,800 & 5,897 & 16,193 & 1,793 & 52,717 & 204,418 \\
\hline & & \multicolumn{9}{|c|}{ Annual Average Ex-Vessel Value in Thousands of 2006 Dollars } \\
\hline 1986-1990 & 79,642 & 121,862 & 6,583 & 2,222 & 5 & 469 & 434 & 4,423 & 20,129 & 235,769 \\
\hline 1991-1995 & 52,487 & 91,287 & 12,339 & 1,665 & 182 & 3,896 & 30 & 3,871 & 13,634 & 179,393 \\
\hline $1996-2000$ & 35,106 & 71,259 & 15,949 & 534 & 127 & 3,230 & 255 & 6,966 & 16,893 & 150,318 \\
\hline 2001-2006 & 41,473 & 161,251 & 9,669 & 1,487 & 1,627 & 2,627 & 3,106 & 10,711 & 12,651 & 244,602 \\
\hline
\end{tabular}


Table 3. New Bedford-Fairhaven Waterfront Land Uses by Categories

\begin{tabular}{crrrrrrr}
\hline Year & & & & & & Marine & Total \\
Pishing & Processing & Repair Transport & Boating & Total & Parcels \\
\hline $1986-1990$ & 20 & 40 & 29 & 16 & 14 & 101 & 356 \\
$1991-1995$ & 21 & 44 & 31 & 14 & 16 & 107 & 356 \\
$1996-2000$ & 23 & 46 & 31 & 12 & 19 & 109 & 356 \\
$2001-2006$ & 24 & 54 & 36 & 16 & 19 & 124 & 358 \\
\hline
\end{tabular}

Unit: Number of parcels.

Fishing: commercial fishing vessel docking, storage, and parking facilities.

Processing: fish processing facilities.

Repair: marine supply and repair facilities.

Transport: transport, packaging, cold storage facilities.

Boating: marinas, recreational boating, boat storage, recreation and docking facilities.

The numbers of parcels for individual marine uses do not sum to those of the marine totals due to multiple uses (e.g., fishing and processing, boating and repair). 
Table 4. New Bedford-Fairhaven Land Use Model: Variables, Measurements, and Descriptive Statistics

\begin{tabular}{|c|c|c|c|c|c|}
\hline Variable & Measurement & Mean & Std Dev & Min & Max \\
\hline \multicolumn{6}{|c|}{ Dependent variables } \\
\hline Marine $5^{\mathrm{a}}$ & 1 for marine uses, 0 otherwise & 0.31 & 0.46 & 0 & 1 \\
\hline Marine $4^{\mathrm{b}}$ & 1 for marine uses, 0 otherwise & 0.28 & 0.45 & 0 & 1 \\
\hline Processing & $\begin{array}{l}1 \text { for fish processing, } 0 \\
\text { otherwise }\end{array}$ & 0.13 & 0.34 & 0 & 1 \\
\hline \multicolumn{6}{|c|}{ Independent variables } \\
\hline Scallop Stock & kilograms/tow & 3.03 & 2.49 & 0.95 & 7.17 \\
\hline Groundfish & kilograms/tow & 24.23 & 11.65 & 12.84 & 42.98 \\
\hline Monkfish & kilograms/tow & 0.86 & 0.13 & 0.75 & 1.07 \\
\hline Area & square meters/parcel & $3,621.79$ & $5,980.31$ & 30.24 & $41,085.22$ \\
\hline ln Area & natural logarithm of Area & 7.29 & 1.35 & 3.41 & 10.62 \\
\hline Fairhaven & $\begin{array}{l}1 \text { for parcel in Fairhaven, } 0 \\
\text { otherwise }\end{array}$ & 0.54 & 0.50 & 0 & 1 \\
\hline $\mathrm{DPA}$ & $\begin{array}{l}1 \text { for designated port area, } 0 \\
\text { otherwise }\end{array}$ & 0.46 & 0.50 & 0 & 1 \\
\hline
\end{tabular}

a. Marine 5 includes commercial fishing, fish processing, marine supply/repair, transport/packaging, and recreational boating.

b. Marine 4 includes commercial fishing, fish processing, marine supply/repair, and transport/packaging. 
Table 5. New Bedford-Fairhaven Marine Land Use Probability: Logit Estimates

\begin{tabular}{|c|c|c|c|c|c|}
\hline \multirow[t]{2}{*}{ Variable } & \multirow[t]{2}{*}{$\begin{array}{c}\text { Model I } \\
\text { (Marine 5) }\end{array}$} & $\begin{array}{c}\text { Model II } \\
\text { (Marine 4) }\end{array}$ & $\begin{array}{c}\text { Model III } \\
\text { (Marine 5) }\end{array}$ & \multirow[t]{2}{*}{$\begin{array}{l}\text { Model IV } \\
\text { (Marine 5) }\end{array}$} & \multirow[t]{2}{*}{$\begin{array}{c}\text { Marginal } \\
\text { Probability }\end{array}$} \\
\hline & & \multicolumn{2}{|c|}{ Coefficient (p-value) } & & \\
\hline \multirow[t]{2}{*}{ Scallop Stock } & $0.0505^{* *}$ & $0.0500^{*}$ & $0.0545^{* *}$ & $0.1025^{* *}$ & $1.55 \%$ \\
\hline & $(0.0480)$ & $(0.0619)$ & $(0.0410)$ & $(0.0497)$ & \\
\hline \multirow[t]{2}{*}{ ln Area } & $0.4604^{* * *}$ & $0.4000^{* * *}$ & $0.4028^{* * *}$ & $0.2854^{* *}$ & $4.31 \%$ \\
\hline & $(<0.0001)$ & $(<0.0001)$ & $(<0.0001)$ & $(0.0123)$ & \\
\hline \multirow[t]{2}{*}{ Fairhaven } & $-1.2239^{* * *}$ & $-1.6786^{* * *}$ & (1) & -0.4586 & $-6.92 \%$ \\
\hline & $(<0.0001)$ & $(<0.0001)$ & & $(0.4166)$ & \\
\hline \multirow[t]{2}{*}{ DPA } & - & - & $1.8711^{* * *}$ & $1.2350^{* *}$ & $18.63 \%$ \\
\hline & & & $(<0.0001)$ & $(0.0179)_{* * *}$ & \\
\hline Lagged land use & - & - & - & $5.3535^{* * *}$ & $80.75 \%$ \\
\hline \multirow[t]{2}{*}{ Intercept } & $-3.8626^{* * *}$ & $-3.4329^{* * *}$ & $-5.0667^{* * *}$ & $-5.7755^{* * *}$ & $-87.12 \%$ \\
\hline & $(<0.0001)$ & $(<0.0001)$ & $(<0.0001)$ & $(<0.0001)$ & \\
\hline \# of observations & 1,426 & 1,426 & 1,426 & 1,069 & \\
\hline \# of marine & 441 & 397 & 441 & 340 & \\
\hline \# of nonmarine & 985 & 1,029 & 985 & 729 & \\
\hline Likelihood ratio test & 306.05 & 346.56 & 402.36 & 932.45 & \\
\hline
\end{tabular}

$*, * *$ and $* * *$ against the reported coefficients denote significance at $10,5,1 \%$ significance level, respectively.

${ }^{\S}$ Marginal change in land use switch probability with respect to change in each independent variable based on Model IV results and calculated using Equation (6). 
Table 6. New Bedford Marine Land Use Probability: Logit Estimates

\begin{tabular}{|c|c|c|c|c|c|}
\hline Variable & $\begin{array}{l}\text { Model V } \\
\text { (Marine 5) }\end{array}$ & $\begin{array}{c}\text { Model VI } \\
\text { (Processing) } \\
\text { Coefficien } \\
\end{array}$ & $\begin{array}{l}\text { Model VII } \\
\text { (Marine 4) } \\
\text { (p-value) } \\
\end{array}$ & $\begin{array}{l}\text { Model VIII } \\
\text { (Marine 5) }\end{array}$ & $\begin{array}{c}\text { Marginal } \\
\text { Probability }\end{array}$ \\
\hline Scallop Stock & $\begin{array}{l}0.0857^{* * *} \\
(0.0086)\end{array}$ & $\begin{array}{c}0.0609^{*} \\
(0.0787)\end{array}$ & $\begin{array}{c}0.0739^{* *} \\
(0.0228)\end{array}$ & $\begin{array}{c}0.1267^{* *} \\
(0.0316)\end{array}$ & $2.14 \%$ \\
\hline $\ln$ Area & $\begin{array}{c}0.3468^{* * *} \\
(<0.0001)\end{array}$ & $\begin{array}{l}0.2179^{* * *} \\
(0.0057)\end{array}$ & $\begin{array}{c}0.3468^{* * *} \\
(<0.0001)\end{array}$ & $\begin{array}{l}0.2534^{* *} \\
(0.0476)\end{array}$ & $8.67 \%$ \\
\hline DPA & $\begin{array}{c}1.1304^{* * *} \\
(0.0007)\end{array}$ & $\begin{array}{c}0.5712 \\
(0.1296)\end{array}$ & $\begin{array}{c}1.2761^{* * *} \\
(0.0002)\end{array}$ & $\begin{array}{c}0.5839 \\
(0.3199)\end{array}$ & $28.25 \%$ \\
\hline Lagged land use & - & - & - & $\begin{array}{c}4.7043^{* * *} \\
(<0.0001)\end{array}$ & \\
\hline Intercept & $\begin{array}{c}-4.0915^{* * *} \\
(<0.0001)\end{array}$ & $\begin{array}{c}-3.4944^{* * *} \\
(<0.0001)\end{array}$ & $\begin{array}{c}-4.2569^{* * *} \\
(<0.0001)\end{array}$ & $\begin{array}{l}-4.8455^{* * *} \\
(0.0002)\end{array}$ & $-102.25 \%$ \\
\hline \# of observations & 654 & 654 & 654 & 490 & \\
\hline \# of marine & 334 & 178 & 324 & 261 & \\
\hline \# of nonmarine & 320 & 476 & 330 & 229 & \\
\hline Likelihood ratio test & 38.44 & 12.06 & 38.84 & 380.56 & \\
\hline
\end{tabular}

$*$, ** and $* * *$ against the reported coefficients denote significance at 10, 5, 1\% significance level, respectively.

$\S$ Marginal change in land use switch probability with respect to change in each independent variable based on Model V results and calculated using Equation (6). 
Table 7. New Bedford-Fairhaven Marine Land Use Probability: Logit Estimates for Different Stocks

\begin{tabular}{|c|c|c|c|}
\hline Variable & $\begin{array}{r}\text { Model IX } \\
\text { (Groundfish) } \\
\text { Coeff }\end{array}$ & $\begin{array}{c}\text { Model X } \\
\text { (Monkfish) } \\
\text { ient (p-value) }\end{array}$ & $\begin{array}{c}\text { Model XI } \\
\left(\text { (3 Species }^{\S}\right)\end{array}$ \\
\hline Stock & $\begin{array}{c}0.0105^{* *} \\
(0.0480)\end{array}$ & $\begin{array}{r}0.7409 \\
(0.1428)\end{array}$ & $\begin{array}{c}0.0087^{*} \\
(0.0533)\end{array}$ \\
\hline ln Area & $\begin{array}{c}0.4603^{* * *} \\
(<0.0001)\end{array}$ & $\begin{aligned} & 0.4597^{* * *} \\
&(<0.0001)\end{aligned}$ & $\begin{array}{c}0.4603^{* * *} \\
(<0.0001)\end{array}$ \\
\hline Fairhaven & $\begin{array}{c}-1.2237^{* * *} \\
(<0.0001)\end{array}$ & $\begin{array}{c}-1.2223^{* * *} \\
(<0.0001)\end{array}$ & $\begin{array}{l}-1.2237^{* * *} \\
(<0.0001)\end{array}$ \\
\hline Intercept & $\begin{array}{c}-3.9640^{* * *} \\
(<0.0001)\end{array}$ & $\begin{array}{c}-4.3472^{* * *} \\
(<0.0001)\end{array}$ & $\begin{array}{c}-3.9526^{* * * *} \\
(<0.0001)\end{array}$ \\
\hline \# of observations & 1,426 & 1,426 & 1,426 \\
\hline \# of marine & 441 & 441 & 441 \\
\hline \# of nonmarine & 985 & 985 & 985 \\
\hline Likelihood ratio test & 308.84 & 304.30 & 305.88 \\
\hline
\end{tabular}

$*$, ** and $* * *$ against the reported coefficients denote significance at $10,5,1 \%$ significance level, respectively.

Marine 5 is the dependent variable in Models IX, X, and XI.

$\S$ The sum of abundance indices for scallops, groundfish, and monkfish 